\title{
Performance of FLD Intervention on Yield of Sunflower (Helianthus annus L.) in Bihar, India
}

\author{
Vikram Bharati ${ }^{*}$, U.K. Singh ${ }^{2}$, A.K. Paswan $^{3}$ and M.N. Ansari ${ }^{3}$ \\ ${ }^{1}$ Department of Agronomy, ${ }^{2}$ Department of Plant Breeding, Dr. Rajendra Prasad Central \\ Agricultural University, Bihar, Pusa-848 125, India \\ ${ }^{3}$ Department of Extension Education, T.C.A, Dholi- 843 121, India \\ *Corresponding author
}

\section{A B S T R A C T}

\begin{tabular}{l} 
Ke y w o r d s \\
Performance, \\
$\begin{array}{l}\text { Sunflower, Front } \\
\text { line demonstration }\end{array}$ \\
\hline Article Info \\
$\begin{array}{l}\text { Accepted: } \\
\text { 24 February } 2018 \\
\text { Available Online: } \\
\text { 10 March } 2018\end{array}$ \\
\hline
\end{tabular}

Keywords

Performance, Sunflower, Front

\section{Introduction}

Sunflower (Helianthus annus L.) is one of the most important oilseed crops in India and it ranks third after soybean and groundnut as a source of edible oil. It holds great promises as an edible oilseed crop because of its short duration, photo insensitivity, higher yield potential and wide adoptability to different agro-climatic regions and soil types.

It is a versatile crop which can be grown in any season of the year and it is rich in polyunsaturated fatty acid (PUFA) as well as high vitamin E content. In India, sunflower is cultivated over an area of about 0.73 million hectares with a production of 0.53 million tonnes and productivity of $712 \mathrm{~kg}$ per hectare (Directorate of Economics and Statistics, Ministry of Agriculture and cooperation, government of India, 2012-2013).

The cultivation of sunflower is largely confined to southern parts of the country comprising the states of Karnataka, Maharashtra, Tamil Nadu and Andhra Pradesh. Karnataka is the leading sunflower producing state. However, recently sunflower has moved to northern parts of the country where the productivity is very high. In Bihar, 
sunflower is cultivated over an area of about 0.31 million hectare with a production of 0.22 million tonnes and productivity of $1402 \mathrm{~kg}$ per hectare (Nayak et al., 2013). This requires a momentum through varietal and technological development, transfer and dissemination of improved technology to the grass root level. Therefore, an attempt has been made to ascertain the performance of FLD intervention on yield of sunflower in Bihar.

\section{Materials and Methods}

The frontline demonstrations were conducted in Nalanda, Muzaffarpur, Vaishali and Samastipur district of Bihar. FLD on hybrid and composite variety of Sunflower were conducted by AICRP, Dholi centre from Rabi /spring 2012 to 2016 at various farmers field. During this period 94 FLD's were conducts using hybrid and composite varieties i.e., DRS- 1, KBSH-41, KBSH-44 KBSH-53.Well before conduct of demonstrations, training to the farmers of respective villages was imparted with respect to envisaged technological interventions. All other steps like site and farmer's selection, layout of demonstration and farmers participation etc. were followed as suggested by (Choudhary 1999). To estimate the Technological Gap, Extension Gap and the Technological Index the following formulae have been used (Samui et al., 2000).

Technology gap $=$ Potential yieldDemonstration yield

Extension gap $=$ Demonstration yieldFarmers yield

Potential yield - Demonstration yield Technology index =

Potential yield

\section{Results and Discussion}

The results of the study as well relevant discussion have summarized under the following heads:

\section{Performance of front line demonstration}

A comparison of productivity levels between improved technology and farmers practice yield is shown in Table 1. During the period under study it was observed that front line demonstrations on improved technological practice of Sunflower varieties i.e., DRSH- 1, KBSH-41, KBSH-44 KBSH-53 recorded average total grain yield $(15.77 \mathrm{q} / \mathrm{ha})$ and the percent increase in yield was 25.06 percent higher over the farmers practice yield (12.49q/ha).

In the case of improved technological practice, satisfactory growth i.e. $30.81 \%$ increase in yield of Sunflower was observed during the years 2016. During the year 2013, variety KBSH-53 recorded lowest percent (18.59) increase in grain yield.

Among the varieties DRSH-1 was found superior and the KBSH-41, KBSH-44 KBSH53 yield increase was by, 30.81, 26.49, 24.93, and 24.47 percent respectively. Similar yield enhancement in different crops in front line demonstration has amply been documented by Mishra et al., (2009) and Dhaka et al., (2010).

Yield of front line demonstration trials and Farmers practice of the crop was compared to estimate the yield gaps, which were further categorised into technology index.

Highest technological gap (7.52\%) was observed in the variety KBSH-53. The observed technology gap may be attributed to dissimilarities in soil fertility, salinity and erratic rain fall and other vagaries of weather conditions in the area. 
Table.1 Mean Performance of improved technology and farmers' practice of Sunflower at different location of Bihar

\begin{tabular}{|c|c|c|c|c|c|c|c|c|}
\hline \multirow{2}{*}{$\begin{array}{l}\text { Sl. } \\
\text { No. }\end{array}$} & \multirow[t]{2}{*}{ Year } & \multirow{2}{*}{$\begin{array}{c}\text { No. of } \\
\text { Demonstration }\end{array}$} & \multirow{2}{*}{$\begin{array}{c}\text { Area in } \\
\text { Acre }\end{array}$} & \multirow[t]{2}{*}{ Varieties } & \multicolumn{3}{|c|}{ Yield (q /ha.) } & \multirow{2}{*}{$\begin{array}{c}\% \\
\text { increase } \\
\text { in Yield }\end{array}$} \\
\hline & & & & & IT & FP & $\begin{array}{c}\text { State } \\
\text { Productivit } \\
\text { y (q/ha) }\end{array}$ & \\
\hline 1. & 2012 & 15 & 15 & KBSH-44 & 13.73 & 10.99 & 14.25 & 24.93 \\
\hline 2. & 2013 & 30 & 15 & KBSH-53 & 14.48 & 12.21 & 14.29 & 18.59 \\
\hline 3. & 2014 & 13 & 13 & KBSH-41 & 17.67 & 13.97 & 14.29 & 26.49 \\
\hline 4. & 2015 & 16 & 15.5 & DRSH-1 & 17.60 & 13.54 & 14.14 & 24.47 \\
\hline 5. & 2016 & 20 & 20 & DRSH-1 & 15.37 & 11.75 & 14.20 & 30.81 \\
\hline & al:- & 94 & & & 15.77 & 12.49 & 14.23 & 25.06 \\
\hline
\end{tabular}

Table.2 Productivity, yield gap and technology index of sunflower

\begin{tabular}{|c|c|c|c|c|c|c|c|c|c|}
\hline \multirow{2}{*}{$\begin{array}{l}\text { Sl. } \\
\text { No }\end{array}$} & \multirow[t]{2}{*}{ Varieties } & \multirow[t]{2}{*}{ Years } & \multirow{2}{*}{$\begin{array}{l}\text { No. of } \\
\text { Demonst } \\
\text { ration }\end{array}$} & \multicolumn{3}{|c|}{ Yield (q/ha.) } & \multicolumn{2}{|c|}{ Gap } & \multirow{2}{*}{$\begin{array}{l}\text { Technology } \\
\text { index }\end{array}$} \\
\hline & & & & Potential & $\begin{array}{c}\text { Demonstr } \\
\text { ation }\end{array}$ & $\begin{array}{l}\text { Farmer } \\
\text { s Yield }\end{array}$ & $\begin{array}{c}\text { Technolog } \\
\mathbf{y}\end{array}$ & Extension & \\
\hline 1. & KBSH-44 & 2012 & 15 & 18.00 & 13.73 & 10.99 & 4.27 & 2.74 & 23.72 \\
\hline 2. & KBSH-53 & 2013 & 30 & 22.00 & 14.48 & 12.21 & 7.52 & 2.27 & 34.18 \\
\hline 3. & KBSH-41 & 2014 & 13 & 20.00 & 17.67 & 13.97 & 2.33 & 3.70 & 11.65 \\
\hline 4. & DRSH-1 & 2015 & 16 & 22.00 & 17.60 & 13.54 & 4.40 & 4.06 & 20.00 \\
\hline 5. & DRSH-1 & 2016 & 20 & 22.00 & 15.37 & 11.75 & 6.63 & 3.62 & 30.14 \\
\hline
\end{tabular}

The highest extension gap was found in the variety DRSH-1, which was followed by KBSH-41 and KBSH-44, which emphasised the need to educate the farmers through various means for the adoption of high yielding sunflower verities and among agro technologies to reverse this trend of extension gap. More and more use of new sunflower hybrids varieties by the farmers will subsequently change this alarming trend of galloping extension gap. The lower the value of technology index more is the feasibility.

Table 2 also revealed that the technology index was lowest in the variety KBSH- 41 . The findings of present study are in line with the findings of Sawardekar et al., (2003), Hiremath and Nagraju (2009). Farmers were motivated by results of improved varieties and agro technologies applied in the FLDS trials and it is expected that they would adopt these technologies in the coming years.

The Front Line Demonstrations (FLDs) enhanced the yield of crops vertically and ensured rapid spread of technologies horizontally. The FLDs made positive and significant impact on yield enhancement of sunflower by 25.06 per cent. It was found FLD is proven extension intervention to demonstrate the production potential of sunflower crop on farmer's field. Therefore, it is recommended that stakeholders who are engaged in transfer and application of agriculture technologies on farmer's field should give priority to organize Front Line Demonstrations (FLDs) extensively in cluster approach for enhancing productivity potential 
of main crops and to make rapid spread of flagship technologies. Most of the low yielding local varieties are replaced due to FLDs. Therefore, it is suggested that policy maker may provide adequate financial support to frontline extension system for organizing FLDs under close supervision of agricultural scientists and extension personnel. This may help to raise the agricultural productivity at district, state and national level.

\section{References}

Choudhary B.N. 1999. Krishi Vigyan KendraA guide for KVK Manager. Publication division of Agricultural Extension, ICAR-pp. 73-78

Dkaka, B.L., Meena B.S and Suwalka, R.L. 2010. Popularization of improved maize production technology through front line demonstration in Southern Rajasthan. Journal of Agricultural Sciences 1(1): 39-42

Hiremath, S.M. and Nagaraju, M.V. 2009. Evaluation of front line demonstration trials on onion in Haveri district of Karnataka. Karnataka Journal of Agricultural Sciences 22(5): 1092-1093.

Mishra, D. K., Paliwal D. K., Tailor R. S. and Deshwal A.K. 2009. Impact of frontline demonstrations on yield enhancement of potato. Indian Research Journal of Extension education 9(3): 26-29.

Nayak A., Gracy, C.P., Nagasree, N. and Girisha, K. 2013. Online www.krishisewa.com/articles/miscellan eous/284- Sunflower.html

Samui, S.K., Maitra, S., Roy, D.K., Mondal, A.K. and Saha, D. 2000. Evaluation on front line demonstration on groundnut (Arachis hypogea L.). Journal of Indian Society Coastal Agricultural Research 18(2): 180-183

Sawardekar, S.V., Dhane, S.S. and Jahav, B.B (2003). Front line demonstration performance of salt tolerant rice varieties in coastal saline soil. IRRN, 28(1): 73-74

\section{How to cite this article:}

Vikram Bharati, U.K. Singh, A.K. Paswan and Ansari, M.N. 2018. Performance of FLD Intervention on Yield of Sunflower (Helianthus annus L.) in Bihar, India. Int.J.Curr.Microbiol.App.Sci. 7(03): 2878-2881. doi: https://doi.org/10.20546/ijcmas.2018.703.332 